\title{
Determination of heavy metals in tomatoes cultivated under green houses and human health risk assessment
}

\author{
A. Bounar ${ }^{1,2}$, K. Boukaka ${ }^{1,2}$ and E. Leghouchi ${ }^{1}$ \\ ${ }^{1}$ Laboratoire de Biotechnologie, Environnement et Santé. Université Mohammed Seddik BENYAHYA- Jijel. Algerie; \\ ${ }^{2}$ Laboratoire de Pharmacologie et Phytochimie. Université Mohammed Seddik BENYAHYA- Jijel. Algerie
}

Corresponding Author: A. Bounar, bounaramina@yahoo.fr

Received: 17 January 2019 / Accepted: 07 January 2020 / Published: 03 March 2020

(C) 2020 Codon Publications

OPEN ACCESS @C) (1) (2) RESEARCH ARTICLE

\begin{abstract}
The present work aims to assess the levels of some heavy metals in agricultural soils and Tomatoes in Jijel (Algeria). The soil samples were extracted by aqua regia and fluorhydric acid methods. The tomato's digestion was realised by the Hoening methods. Lead, Cadmium (Cd) and Zinc levels were measured using Atomic Absorption Spectrometry. According to the integrated pollution index, all the sites are slightly polluted by heavy metals. In tomatoes, lead $(\mathrm{Pb})$ and Cd concentrations exceeded the standards set by the World Health Organization (WHO)/Food and Agriculture Organization (FAO). In general, the hazard indexes in all the studied area are less than 1, signifying that it is not risky for the people to consume these elements. However, the hazard quotients for $\mathrm{Cd}$ in sites 5, 6 and 7 are greater than 1 , suggesting that inhabitants are experiencing a significant potential health risk especially from the consumption of tomatoes cultivated in these sites. To the best of our knowledge, this is the first study conducted on the agricultural soils of Jijel, and this could serve as a reference for future studies to monitor pollution in Jijel and its surrounding areas.
\end{abstract}

Keywords: health risk, heavy metals, pollution, soil, tomatoes

\section{Introduction}

The soil is a natural component of the earth consisting of water, air, living organisms, organic matter and mineral particles (Calvet, 2003; Wei and Yang, 2010). Among these mineral particles, there are heavy metals with a density higher than $5 \mathrm{~g} / \mathrm{cm}^{3}$. In environmental monitoring, trace elements are often called 'heavy metals'. While some are trace elements (copper [Cu], Zinc [Zn], nickel [Ni]) essential for the living beings, including humans, that become toxic at high concentrations, others are just heavy metals such as lead $(\mathrm{Pb})$ and cadmium $(\mathrm{Cd})$ with an unknown physiological role and pose a threat to the ecosystem and the living organism health if they exceed some threshold concentrations (Abrid et al., 2013; Soubrand-Colin, 2004). Excessive use of fertilisers and pesticides, sewage irrigation, sewage sludge application and high atmospheric deposition cause a considerable increase in the concentrations of heavy metals in agricultural soils (Alghobar and Suresha, 2017; Cai et al., 2009). Due to the adverse effects of heavy metals on the ecosystem and their potential threat to food safety, soil contamination by these elements is attracting a great attention from the scientific community (Lu et al., 2012). The presence of these metals in agricultural soils is a growing concern because of their accumulation, transfer into soil solution and their ability to degrade the quality of groundwater and crops (Harmanescu et al., 2011; Kelepertzis, 2014; Zheng et al., 2013). One of the alarming facts is that crops cultivated in soils polluted with heavy metals tend to accumulate them in their edible and non-edible parts in quantities high enough to cause clinical symptoms to both animals and human beings. Moreover, the human body lacks a good mechanism for the elimination of heavy metals; thus, consumption of metal-rich plants would impose an intensified risk on human health (Alam et al., 2003; Bhuiyan et al., 2011). 
Since independence, Algeria has invested considerably in different economic sectors, notably agriculture. Unfortunately, the latter has not benefitted from any strategy to protect the environment (Kehila et al., 2006; MATE, 2003). Particularly, soil pollution in Algeria is not well investigated and remains to be explored. Ignorance of the existent distribution and degree of soil pollution makes it impossible to devise adequate monitoring strategies and prevention measures against this pollution. The state of Jijel (North-East Algeria) is considered as one of the most fertile zones in North Africa due to the Mediterranean rainy climate. About $41.25 \%$ of the total area of the state $(9,869,500 \mathrm{ha})$ is agricultural land, with high rate of greenhouse agriculture. In fact, in Algeria, Jijel is considered as the leader in production of several fruits and vegetables, including strawberries, peppers and tomatoes. These crops are meant for both local consumption and exportation to several parts of the world.

Due to the importance of agricultural activity in Jijelnationally and internationally - the present study aims to assess the level of heavy metals ( $\mathrm{Pb}, \mathrm{Cd}$ and $\mathrm{Zn}$ ) contaminating the agricultural soils and vegetables (Tomatoes) under greenhouses in Jijel (North Algeria) using two methods of extraction, aqua regia and fluorhydric acid, on the one hand, and to evaluate the potential health risks of $\mathrm{Pb}, \mathrm{Cd}$ and $\mathrm{Zn}$ to local population through vegetable (tomato) consumption, on the other hand. The results of this study will provide a better understanding of the accumulation characteristics and health risks of heavy metals in a greenhouse vegetable production system.

\section{Material and methods}

The field study sites were located in agricultural zones where greenhouse culture is widely practised. Eight sites were selected; in each site, six composite soil samples (four samples and two controls) were collected at a depth of 10 to $15 \mathrm{~cm}$ using a stainless auger from the greenhouses used for tomato cultivation. The samples were stored in plastic bags. Crop samples were collected at each floor. The locations of sampling sites are shown in Figure 1.

The soil samples were dried at room temperature, crushed and ground to pass through $2 \mathrm{~mm}$ stainless steel sieve according to NF ISO 11464 standards. The soil pH was measured in water in accordance with ISO 10390 standards (Kouchou et al., 2017). Conductivity value in 1:5 (V/V) was determined by conductimeter (Mathieu and Pieltain, 2003). Carbon content was determined with a calcimeter (Mathieu and Pieltain, 2003). The organic matter was measured by calcination at $500{ }^{\circ} \mathrm{C}$ at $5 \mathrm{~h}$ (ISO 10694). Cation exchange capacity (CEC) was estimated using Rhein methods (Mathieu and Pieltain, 2003). The 'pseudo-total' contents of metals were analysed using aqua regia extraction; samples were digested with a hydrochloric (37\%) and nitric (70\%) acids mixture in a ratio of $3: 1$ $(\mathrm{V} / \mathrm{V})$ (ISO 11466). Total contents were determined with

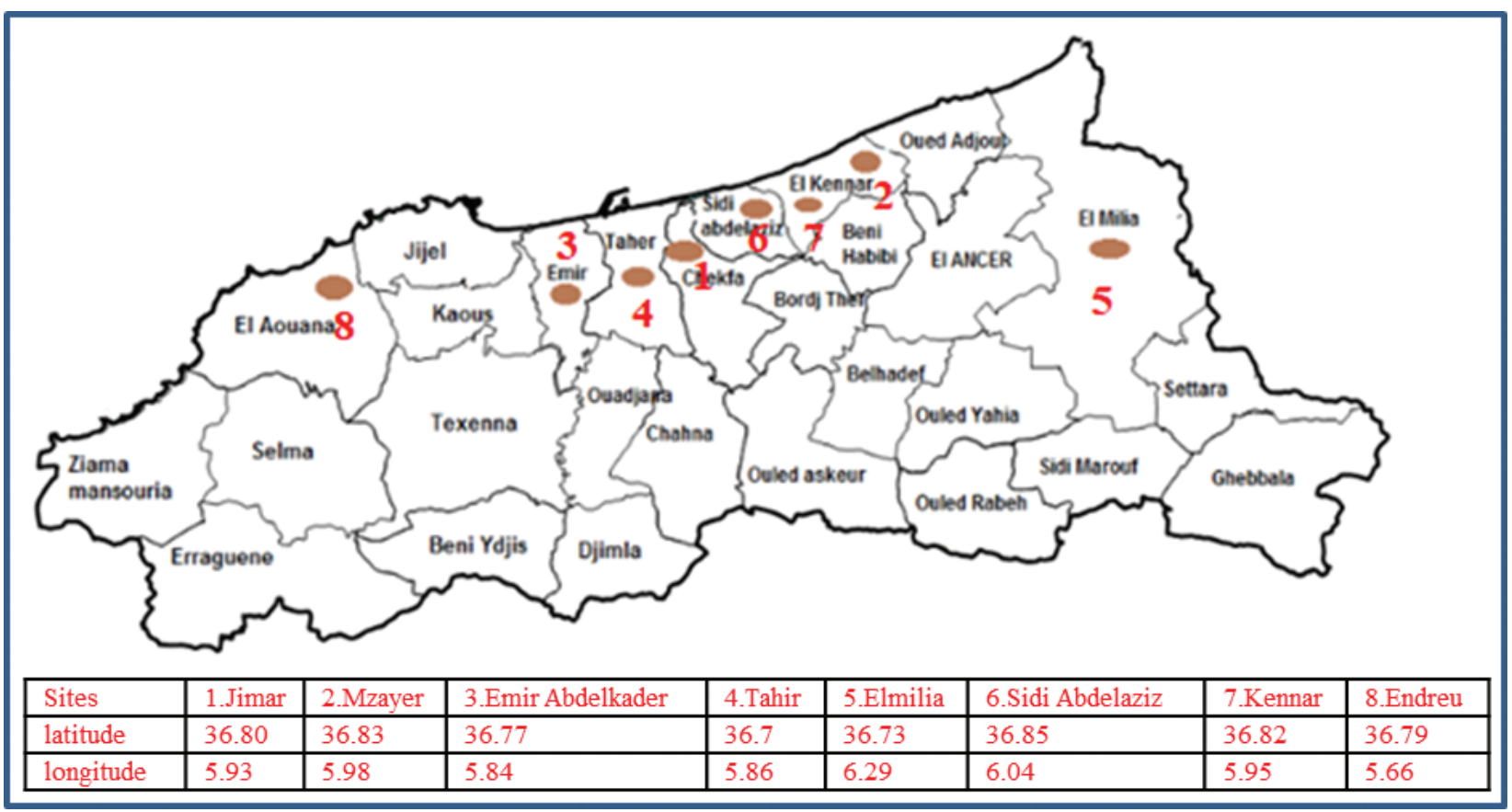

Figure 1. Map of the study area showing the sampling points. 
hydrofluoric (40\%) and perchloric (70\%) acids (NF X31147) (AFNOR, 1996). Samples of tomatoes were washed, mixed and heavy metal contents were determined according to Hoenig and Thomas (2002). Heavy metal concentrations were measured using Atomic Absorption Spectrometry flame AAS (SCIMAGZU AA-6200).

The Pollution Index (PI) was calculated according to Chon et al. (1998). It is defined as the average of the ratios of the metal concentrations in the soil samples to the threshold values.

$$
\mathrm{PI}=\mathrm{C}_{\mathrm{i}} / \mathrm{C}_{0 \mathrm{i}}
$$

Where: $\mathrm{C}_{\mathrm{i}}$ is the concentration of a given $i$ th element in soil samples $(\mathrm{mg} / \mathrm{kg}) ; \mathrm{C}_{0 \mathrm{i}}$ is its corresponding standards concentration $(\mathrm{mg} / \mathrm{kg})$.

To assess the global pollution status of the soil, the Integrated Pollution Index (IPI) can be used (Chen et al., 2015; Liu et al., 2013; Wei and Yang, 2010; Yu et al., 2016; Zeng et al., 2018). The latter is calculated according to the following equation:

$$
\mathrm{IPI}=\sqrt{\left(p_{\text {imax }}^{2}+p_{\text {iave }}^{2}\right) / 2}
$$

Where: $\mathrm{P}_{\text {imax }}$ is the maximum value of $\mathrm{PI}_{i}$, and $\mathrm{PI}$ iave is the arithmetic mean value of $\mathrm{PI}_{i}$.

The soil quality concerning heavy metal safety were classified into five grades as follows: I-safety (IPI $\leq 0.7$ ), II-warning $(0.7<$ IPI $\leq 1)$, III-light pollution $(1<$ IPI $\leq 2)$, IV-moderate pollution $(2<\mathrm{IPI} \leq 3)$ and $\mathrm{V}$-heavy pollution (PI > 3) (Yu et al., 2016; Zeng et al., 2018).

The transfer coefficient (TF), also called Bioconcentration Factor (BCF), was calculated according to Bassey et al.

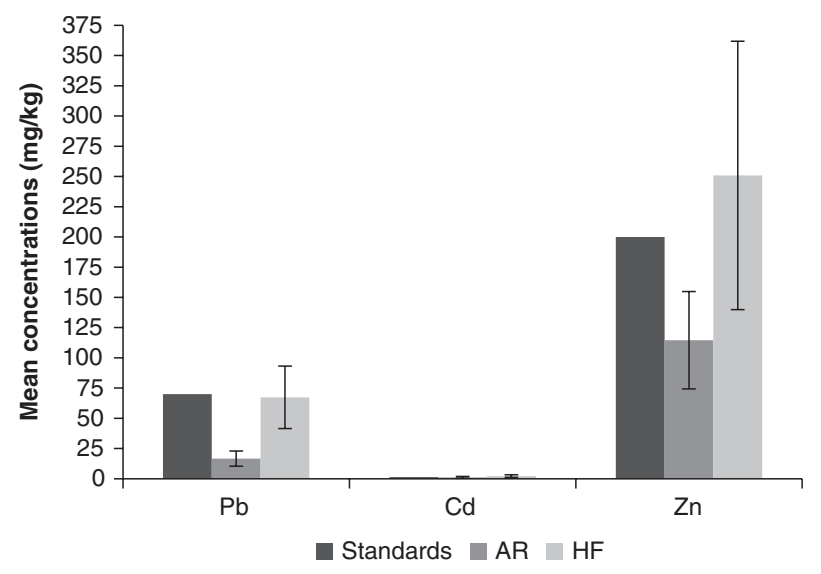

Figure 2. Mean levels of heavy metals extracted by aqua regia and HF comparing with standards
(2014) by dividing the concentration of heavy metals in vegetables by the total heavy metal concentration in the soil.

$\mathrm{TF}=\mathrm{C}_{\text {Plant }} / \mathrm{C}_{\text {Soil }}$

Where, $C_{\text {Plant }}$ is the metal concentration in plant $(\mathrm{mg} / \mathrm{kg})$ and $C_{\text {Soil }}$ : is the metal concentration in soil $(\mathrm{mg} / \mathrm{kg})$.

\section{Human health risk assessment}

Health risk assessment has been recognised as an important tool for identifying risk factors to human health associated with ingestion of heavy metals and providing evidence of risk to the decision-makers. However, estimated daily intake (EDI), hazard quotients (HQ) and hazard index $(\mathrm{HI})$ were used to evaluate the toxicity of pollution and verify the risks it causes to humans (Balkhair and Ashraf, 2016; Han et al., 2018; Hua et al., 2017; Hub et al., 2017; Shahid et al., 2016; Zeng et al., 2018).

The EDI of each metal through food consumption (tomatoes) and the HQ were calculated by the equations:

$$
\begin{aligned}
& \mathrm{EDI}\left(\mathrm{mg} \cdot \mathrm{kg}^{-1} \cdot \mathrm{day}^{-1}\right)=\mathrm{C}_{\mathrm{v}} \times \mathrm{IR} \times \mathrm{EF} \times \mathrm{ED} / \mathrm{BW} \times \mathrm{AT} \\
& \mathrm{HQ}=\mathrm{EDI} / \mathrm{RfD}=\mathrm{C}_{\mathrm{v}} \times \mathrm{IR} \times \mathrm{EF} \times \mathrm{ED} / \mathrm{BW} \times \mathrm{AT} \times \mathrm{RfD}
\end{aligned}
$$

Where $\mathrm{C}_{\mathrm{v}}$ is heavy metal concentrations in the edible parts of vegetables $(\mathrm{mg} / \mathrm{kg})$, IR represents the intake rates of selected dietary (tomatoes) considered to be $0.09 \mathrm{~kg} / \mathrm{per}-$ son/day, EF is exposure frequency (365 days/year were considered due to daily intake of tomatoes by humans), ED is the exposure duration [76 years (Cherfi et al., 2014)], BW is the average body weight [69.6 kg for adult (Atek et al., 2010)], AT is the average time for noncarcinogens (365 days/year $\times$ number of exposure years, assuming 76 years in this study), RfD is the oral reference dose, which is $0.004,0.001,0.03 \mathrm{mg} / \mathrm{kg}$ for $\mathrm{Pb}, \mathrm{Cd}$ and $\mathrm{Zn}$, respectively (USEPA, 2017).

To assess the overall potential for non-carcinogenic effects posed by multiple metals, the HI was applied using the equation:

$\mathrm{HI}=\mathrm{HQ}_{\mathrm{Pb}}+\mathrm{HQ}_{\mathrm{Cd}}+\mathrm{HQ}_{\mathrm{Zn}}$

When HQ or HI is lower than 1, there is no serious risk from exposure to heavy metals; however, if HQ or HI is equal to or higher than 1, the exposed population is likely to experience an adverse (non-carcinogenic) effect.

Statistical analysis was performed using Analysis of variance (ANOVA), and $T$-test $(p<0.05)$ was used to compare data from the different groups of soil samples 
distributed normally. However, if the data were non-normally distributed, non-parametric tests (Kruskal-Wallis and Mann-Whitney tests) were performed.

\section{Results and discussion}

The results of the statistical analysis of chemical properties in the studied area are presented in Table 1. The soil $\mathrm{pH}$ ranged from 6.61 to 7.8 , from neutral to slightly alkaline. The average organic matter content in the plots studied was 3.57-9.51\%, while CEC values of the samples have shown slight variations, with a mean value of $16.74 \mathrm{cmol} / \mathrm{kg}$, thus indicating a greater than adequate CEC for agricultural use (Micó et al., 2006). The Conductivity (CE) ranged from 82.72 to $606.50 \mu \mathrm{S} / \mathrm{cm}$.

Table 1. Statistical values of physicochemical parameters in the topsoil of the study area.

\begin{tabular}{lrrrr} 
& Mean & SD & \multicolumn{2}{c}{ Range } \\
\cline { 4 - 5 } & & & \multicolumn{1}{c}{ Min } & \multicolumn{1}{c}{ Max } \\
\hline pH & 7.15 & 0.31 & 6.61 & 7.80 \\
EC $\left(\mu S . \mathrm{cm}^{-1}\right)$ & 288.79 & 162.60 & 82.72 & 606.50 \\
OM $(\%)$ & 5.53 & 5.17 & 3.57 & 9.51 \\
TC $(\%)$ & 5.99 & 3.55 & 3.10 & 12.96 \\
CEC $\left(\mathrm{cmol}^{-} \mathrm{kg}^{-1}\right)$ & 16.43 & 5.76 & 8.00 & 23.90 \\
Humidity $(\%)$ & 2.50 & 1.26 & 1.06 & 4.66 \\
\hline
\end{tabular}

SD, standard deviation; CEC, cation exchange capacity; EC, Electric Conductivity; OM, Organic Matter; TC, Total Calcium carbonate.
$\mathrm{pH}$ is considered to be the main chemical parameter determining the bioavailability of heavy metals in soil (Brallier et al., 1996); basically, the alkaline $\mathrm{pH}$ limits the passage of heavy metals from the solid phase to the solution of the soil and then to the plant (Jung and Thornton, 1996). In this study, the $\mathrm{pH}$ values were mostly neutral, and they are comparable to those found in the soils of the neighbouring areas such as Ghazaouet (North Algeria) (Kebir and Bouhadjera, 2011), Mamora and Casablanca (North Morocco) (Kassaoui et al., 2009; Matech et al., 2014).

The rate of organic matter in soil varies; generally, a rate of organic matter between 4 and $8 \%$ reflects good productivity and good mineralisation capacity (Badra and Qu, 2005). Electric Conductivity (EC) reflects soil salinity; high $\mathrm{EC}$ in the range of $600 \mu \mathrm{s} / \mathrm{cm}$ may affect salt-sensitive crops (Kassaoui et al., 2009). In the present study, we registered values around $288.79 \mu \mathrm{s} / \mathrm{cm}$; according to Durand (1983), these values reflect a negligible soil salinity.

The concentrations of three heavy metals $(\mathrm{Pb}, \mathrm{Cd}$ and $\mathrm{Zn}$ ) extracted by aqua regia and fluorhydric acid in this study are presented in Tables 2 and 3, respectively. The values of $\mathrm{Pb}, \mathrm{Cd}$ and $\mathrm{Zn}$ (extracted by aqua regia) are $16.66 \pm 6.26 \mathrm{mg} / \mathrm{kg}, 1.14 \pm 0.73 \mathrm{mg} / \mathrm{kg}$ and $114.61 \pm 40.27$ $\mathrm{mg} / \mathrm{kg}$ respectively and ranged from $9.47 \pm 0.70-27.62 \pm$ $2.65 \mathrm{mg} / \mathrm{kg}, 0.15 \pm 0.05-1.99 \pm 1.8 \mathrm{mg} / \mathrm{kg}$ and $57.60 \pm 40$ - $173.20 \pm 7.36 \mathrm{mg} / \mathrm{kg}$. Pb, Cd and $\mathrm{Zn}$ (extracted by HF) contents ranged from $23.79 \pm 3.12-111.00 \pm 6.39 \mathrm{mg} / \mathrm{kg}$, $0.38 \pm 0.05-3.63 \pm 0.07 \mathrm{mg} / \mathrm{kg}$ and $105.90 \pm 1.27-434.10 \pm$ $36.91 \mathrm{mg} / \mathrm{kg}$ with an average of $67.33 \pm 25.80,2.16 \pm 1.06$

Table 2. Heavy metal levels extracted by aqua regia of agricultural soils in study area.

\begin{tabular}{|c|c|c|c|c|c|c|}
\hline & \multicolumn{2}{|c|}{$\mathrm{Pb}\left(\mathrm{mg} \cdot \mathrm{kg}^{-1}\right)$} & \multicolumn{2}{|c|}{$\mathrm{Cd}\left(\mathrm{mg} \cdot \mathrm{kg}^{-1}\right)$} & \multicolumn{2}{|c|}{$\mathrm{Zn}\left(\mathrm{mg} \cdot \mathrm{kg}^{-1}\right)$} \\
\hline & Inside & Outside & Inside & Outside & Inside & Outside \\
\hline $1 \mathrm{JIM}$ & $22.89 \pm 0.035^{*}$ & $7.50 \pm 3.54$ & $1.72 \pm 0.25^{\star}$ & $0.22 \pm 0.12$ & $118.62 \pm 43.7$ & $63.00 \pm 4.24$ \\
\hline $2 \mathrm{MZY}$ & $27.62 \pm 2.65^{\star}$ & $13.12 \pm 3.18$ & $1.98 \pm 1.86$ & $0.19 \pm 0.07$ & $75.37 \pm 2.65$ & $75.50 \pm 7.42$ \\
\hline 3 EMR & $17.89 \pm 0.16$ & $12.62 \pm 7.57$ & $1.71 \pm 0.39$ & $0.80 \pm 0.46$ & $57.60 \pm 40$ & $55.50 \pm 47.4$ \\
\hline $4 \mathrm{TAH}$ & $13.37 \pm 0.88$ & $18.25 \pm 9.55$ & $0.15 \pm 0.01$ & $0.65 \pm 0.21$ & $103.12 \pm 18^{*}$ & $71.25 \pm 3.89$ \\
\hline 5 ELM & $25.62 \pm 2.47$ & $22.25 \pm 3.54$ & $1.15 \pm 0.49$ & $0.50 \pm 0.49$ & $97.00 \pm 1.24$ & $76.25 \pm 7.07$ \\
\hline $6 \mathrm{SDA}$ & $10.62 \pm 0.53^{*}$ & $15.25 \pm 0.35$ & $0.20 \pm 0.05^{\star}$ & $1.22 \pm 0.49$ & $106.25 \pm 59.9$ & $70.00 \pm 4.95$ \\
\hline $7 \mathrm{KEN}$ & $13.12 \pm 3.18$ & $11.51 \pm 0.00$ & $1.40 \pm 0.53$ & $1.20 \pm 0.25$ & $164.00 \pm 82$ & $66.50 \pm 0.00$ \\
\hline 8 END & $9.47 \pm 0.70$ & $9.76 \pm 1.7$ & $1.45 \pm 0.2$ & $1.07 \pm 0.2$ & $173.20 \pm 7.36^{*}$ & $98.91 \pm 7.19$ \\
\hline Mean \pm SD & $15.57 \pm 7.02$ & $13.78 \pm 4.72$ & $1.14 \pm 0.73$ & $0.81 \pm 0.42$ & $114.61 \pm 40.27$ & $72.11 \pm 12.77$ \\
\hline $\begin{array}{l}\text { Normal content of heavy } \\
\text { metals in soils (Bowen, 1979) }\end{array}$ & \multicolumn{2}{|c|}{35} & \multicolumn{2}{|c|}{0.35} & \multicolumn{2}{|c|}{90} \\
\hline Limit values & \multicolumn{2}{|c|}{$100^{a, b}, 60^{c}, 70^{d}, 50^{e}$} & \multicolumn{2}{|c|}{$2^{a}, 1^{b, c}, 1.4^{d}, 0.3^{e}$} & \multicolumn{2}{|c|}{$300^{a}, 200^{b, c, d}, 250^{e}$} \\
\hline
\end{tabular}

SD, standard deviation; JIM, Jimar; MZY, Mzayer; EMR, Emir Abdelkader; TAH, Tahir; ELM, Elmilia; SDA, Sidi Abdelaziz; KEN, Kennar; END, Endreau. $T$-test was used to compare between the levels of heavy metals outside and inside sites.

${ }^{*} P<0.05$ compared to control (outside site).

${ }^{a}$ WHO/FAO, ${ }^{b}$ Hungarian governmental regulation number 10/2000 (2000), ${ }^{c}$ Ministry of the Environment, Finland (MEF), (2007): ${ }^{d}$ Canadian Council Of Ministers Of The Environment (CCME), 2007, ' ${ }^{e}$ China National Environmental Protection Agency (CNEPA), 2006. 
Table 3. Heavy metals concentrations extracted by HF of agricultural soils in study area.

\begin{tabular}{|c|c|c|c|c|c|c|}
\hline \multirow[t]{2}{*}{ HF } & \multicolumn{2}{|c|}{$\mathrm{Pb}\left(\mathrm{mg} \cdot \mathrm{kg}^{-1}\right)$} & \multicolumn{2}{|c|}{$\mathrm{Cd}\left(\mathrm{mg} \cdot \mathrm{kg}^{-1}\right)$} & \multicolumn{2}{|c|}{$\mathrm{Zn}\left(\mathrm{mg} \cdot \mathrm{kg}^{-1}\right)$} \\
\hline & Inside & Outside & Inside & Outside & Inside & Outside \\
\hline $1 \mathrm{JIM}$ & $111.00 \pm 6.39^{*}$ & $69.35 \pm 3.04$ & $1.93 \pm 0.1^{*}$ & $0.83 \pm 0.25$ & $394.80 \pm 95.03$ & $251.64 \pm 125.75$ \\
\hline $2 \mathrm{MZY}$ & $61.23 \pm 3.92$ & $70.01 \pm 1.42$ & $2.12 \pm 0.16$ & $1.66 \pm 0.08$ & $165.00 \pm 29.69$ & $164.70 \pm 3.81$ \\
\hline 3 EMR & $103.33 \pm 6.74$ & $70.96 \pm 19.14$ & $1.24 \pm 0.50$ & $0.80 \pm 0.27$ & $105.90 \pm 35.49$ & $85.50 \pm 36.13$ \\
\hline $4 \mathrm{TAH}$ & $70.55 \pm 2.04$ & $55.27 \pm 6.04$ & $0.38 \pm 0.05$ & $1.915 \pm 0.47$ & $203.70 \pm 6.36$ & $193.66 \pm 57.27$ \\
\hline 5 ELM & $94.50 \pm 3.88^{*}$ & $43.94 \pm 1.49$ & $1.97 \pm 0.22$ & $0.60 \pm 0.003$ & $213.93 \pm 90.36$ & $268.50 \pm 112.42$ \\
\hline $6 \mathrm{SDA}$ & $42.10 \pm 1.97^{*}$ & $101.73 \pm 6.73$ & $1.75 \pm 0.08^{*}$ & $3.905 \pm 0.13$ & $434.10 \pm 36.91$ & $288.00 \pm 155.56$ \\
\hline 7 KEN & $73.83 \pm 9.59^{*}$ & $23.83 \pm 1.64$ & $3.09 \pm 0.31$ & $3.445 \pm 0.10$ & $246.00 \pm 110.30$ & $152.70 \pm 13.15$ \\
\hline 8 END & $23.79 \pm 3.12^{*}$ & $54.86 \pm 1.21$ & $3.63 \pm 0.46$ & $1.58 \pm 0.05$ & $243.30 \pm 58.12$ & $163.20 \pm 6.78$ \\
\hline Mean \pm SD & $67.33 \pm 25.80$ & $66.45 \pm 28.89$ & $2.16 \pm 1.06$ & $1.77 \pm 1.22$ & $250.84 \pm 111$ & $196.98 \pm 68.62$ \\
\hline
\end{tabular}

SD, standard deviation; HF, hydrofluoric acid; JIM, Jimar; MZY, Mzayer; EMR, Emir Abdelkader; TAH, Tahir; ELM, Elmilia; SDA, Sidi Abdelaziz; KEN, Kennar; END, Endreau.

$T$ test was used to compare between the levels of heavy metals of outside and inside sites

${ }^{*} P<0.05$ compared to control (outside site).

and $240.82 \pm 97.84 \mathrm{mg} / \mathrm{kg}$ respectively, it is worthy to note that the concentration of $\mathrm{Pb}$ (sites 3, 4, 5 and 7), $\mathrm{Cd}$ (sites 1, 2, 5, 6, 7 and 8) and $\mathrm{Zn}$ (sites 1, 4, 5, 6 and 7) extracted by HF exceeds the Canadian limits. Figure 2 represent comparison between the booth extraction and threshold.

The present study showed that the concentrations of $\mathrm{Pb}$ and $\mathrm{Zn}$ extracted by aqua regia in all the studied sites do not exceed the limit of $70 \mathrm{mg} / \mathrm{kg}$ set by the Canadian Council of Ministers of the Environment (CCME). On the other hand, the majority of the sites $(1,2,3,7$, and 8 ) are polluted by $\mathrm{Cd}$ when compared with the CCME standards. It can be seen that the values of $\mathrm{Cd}$ in site 5 is greater than the Chinese limits (CNEPA, 2006). Moreover, these values are comparable to those found in different regions in the world, such as China (Chen et al., 2015) and Nigeria (Ahaneku and Sadiq, 2014). These results are also comparable to those reported in a study conducted on agricultural soils of Annaba, located $300 \mathrm{~km}$ east of Jijel (Maas et al., 2010). While the concentrations of $\mathrm{Pb}$ and $\mathrm{Zn}$ extracted by aqua regia did not exceed the standard limits in all the studied sites, we noticed that they crossed the threshold limits of 70 and $200 \mathrm{mg} / \mathrm{kg}$, respectively, in sites 1, 3, 4, 5 and 7 for $\mathrm{Pb}$ (CCME, 1999) and sites 1, 4, 5, 6 and 7 when extracted by hydrofluoric acid (HF). On the other hand, if we compare the $\mathrm{Pb}$ values in sites 1 and 2 with the lower limits set by the China National Environmental Monitoring Center (CNEMC) $(50 \mathrm{mg} / \mathrm{kg}$ ), we notice that these values exceed the threshold. By HF extraction, Cd also exceeded the standards limits of $1.4 \mathrm{mg} / \mathrm{kg}$ in sites 1 , 2, 5, 6, 7 and 8 (CCME, 1999). However, it is found that $\mathrm{Cd}$ concentrations in all the sites exceed the CNEMC limits $(0.3 \mathrm{mg} / \mathrm{kg})$. In turn, $\mathrm{Zn}$ presented high concentrations that exceeded the threshold of $200 \mathrm{mg} / \mathrm{kg}$ in sites 1, 4, 5, 6 and 7. Site 6 represents the highest concentration (434.10

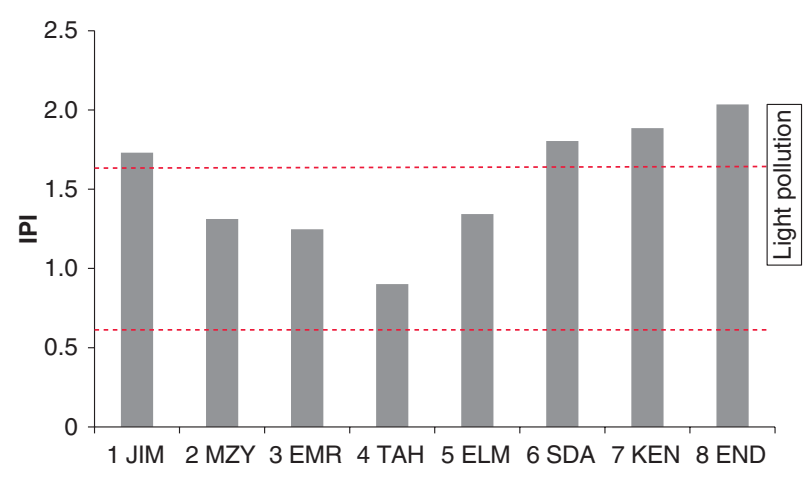

Figure 3. IPls of the studied area.

$\mathrm{mg} / \mathrm{kg}$ ) in the Constantine region; high concentrations of $\mathrm{Zn}$ up to $600 \mathrm{mg} / \mathrm{kg}$ have also been reported using the HF method (Naili et al., 2016).

Taking all together, we evaluated the PI and IPI. According to Chon et al. (1998), PI higher than 1 reflects soil pollution, Figure 3 presents the IPI values of the studied area.

The results of the IPI values show that all the sites are contaminated by heavy metals, with a slight pollution in all the sites, with the exception of sites 8 and 4 that present a moderate pollution and warning limit, respectively. According to the values of the IP, it is noted that pollution by $\mathrm{Pb}$ affects sites 3, 4, 5 and 7 . As for $\mathrm{Cd}$ and $\mathrm{Zn}$, the majority of the sites are contaminated by these elements with a PI higher than 1.

Overall, the values of $\mathrm{Pb}, \mathrm{Cd}$ and $\mathrm{Zn}$ (extracted by $\mathrm{HF}$ ) are close to those obtained using the same method in different regions of the world, such as Guangzhou in China 
(Li et al., 2009), Morocco (Matech et al., 2014) and Congo (Mpundu et al., 2013).

The significant difference between the yields of extraction of the two methods used in this study could be attributed to many factors, namely, the composition of the soil and the chemical nature of the extracted element (Baize, 1997). Scancar et al. (2000) showed a significant difference between the yields of extraction of heavy metals by aqua regia and HF. They attributed this difference to the presence of silicates or refractory aluminium, iron and manganese oxides to which the heavy metals could bound and consequently do not dissolve completely by aqua regia. In the same context, Santoro et al. (2017) reported in their study that when the soil was poor in silicate $\left(\mathrm{SiO}_{2}\right)$ aluminium $\left(\mathrm{Al}_{2} \mathrm{O}_{3}\right)$ and iron oxides $\left(\mathrm{Fe}_{2} \mathrm{O}_{3}\right)$, levels of heavy metals extracted by HF were similar to those extracted by aqua regia.

It can be seen that the concentrations of heavy metals varied from one site to another; this variation could be related to several factors such as the location of the site relatively to pollution sources, the nature of the soil and agricultural practices (Guero et al., 2013). We noticed that in almost all of the studied sites, the $\mathrm{Pb}, \mathrm{Cd}$ and $\mathrm{Zn}$ presented high concentrations in the cultivated soils, compared to the corresponding control soils (collected outside the greenhouses). This variation could be attributed to the use of fertilisers and pesticides. In fact, fertilisers are known to present one of the major sources of agricultural soil contamination by heavy metals (Benson et al., 2014; Brigden et al., 2002; Shahbazi et al., 2017). In this regard, fertilisers used in the region of Jijel have been found to contain high amounts of heavy metals, particularly $\mathrm{Cd}$ (unpublished data), which is in agreement with our results discussed above.

However, we noticed that, particularly in the Sidi Abdelaziz (SDA) site, $\mathrm{Pb}$ and $\mathrm{Cd}$ presented the highest

Table 4. Heavy metal levels in tomatoes.

\begin{tabular}{lccc} 
& Lead $(\mathrm{Pb})$ & Cadmium $(\mathrm{Cd})$ & Zinc $(\mathrm{Zn})$ \\
\hline Site 1 & $1.21 \pm 0.13$ & $0.76 \pm 0.02$ & $7.24 \pm 1.75$ \\
Site 2 & $1.76 \pm 0.16$ & $0.02 \pm 0.00$ & $6.00 \pm 1.02$ \\
Site 3 & $0.46 \pm 0.37$ & $0.16 \pm 0.03$ & $8.50 \pm 1.41$ \\
Site 4 & $1.18 \pm 0.11$ & $0.45 \pm 0.18$ & $6.88 \pm 5.83$ \\
Site 5 & $1.25 \pm 0.01$ & $0.57 \pm 0.01$ & $6.24 \pm 1.52$ \\
Site 6 & $\mathrm{ND}$ & $0.48 \pm 0.04$ & $3.75 \pm 0.01$ \\
Site 7 & $0.73 \pm 0.00$ & $0.68 \pm 0.17$ & $9.25 \pm 4.60$ \\
Site 8 & $\mathrm{ND}$ & $0.48 \pm 0.00$ & $4.75 \pm 1.60$ \\
Mean & $0.82 \pm 0.36$ & $0.45 \pm 0.24$ & $6.57 \pm 1.81$ \\
Standard limit & $0.1^{\mathrm{a}, \mathrm{b}}$ & $0.05^{\mathrm{a}, \mathrm{b}}$ & $50^{\mathrm{c}}$ \\
\hline
\end{tabular}

aEuropean legislation limit values (mg/kg), ${ }^{b}$ WHO/FAO permissible limits, Indian standards. concentrations in soil outside the greenhouses (control), compared to that within the greenhouses; moreover, the outside levels exceeded the standard limits. These results could be explained by the fact that SDA agricultural soils are located alongside the highway, where the soils outside the greenhouses could be contaminated by the by-products of road traffic. In fact, it is well documented that the road traffic activities are the major source of heavy metal emission to roadside soils (Herath et al., 2016; Lygren et al., 1984; Parmentier and Garrec, 1994; Yan et al., 2013; Zeng et al., 2018; Zheng et al., 2016). Furthermore, the SDA site is an agricultural village, characterised by increasing density of housing, which presents another source of pollution in the form of household wastes.

Heavy metal levels in tomatoes, compared to standards, are presented in Table $4 . \mathrm{Pb}$ was detected in the majority of the samples except sites 6 and 8. Mean concentration of $\mathrm{Pb}$ was $0.82 \pm 0.36 \mathrm{mg} / \mathrm{kg}$ and ranged from non-detectable to $1.76 \mathrm{mg} / \mathrm{kg}$. Cd and $\mathrm{Zn}$ were detected in all the samples, and the mean concentrations were $0.45 \pm 0.24$ and $6.57 \pm 1.81 \mathrm{mg} / \mathrm{kg}$, ranging from 0.02 to $0.76 \mathrm{mg} / \mathrm{kg}$ and 3.75 to $9.25 \mathrm{mg} / \mathrm{kg}$, respectively.

The uptake of heavy metals by plants and subsequently their accumulation along the food chain is a potential threat to animal and human health. Most of the daily human intake of heavy metals is due to the consumption of crops (Corguinha et al., 2015). The risk of human exposure to heavy metals through food increases when plants are grown on soils contaminated with heavy metals (Abosede, 2017). In this regard, international guidelines such as those set by the European Union (EU), World Health Organization (WHO)/Food and Agriculture Organization (FAO) are used to set permissible levels of heavy metals in vegetables distended to human consumption. We quantified heavy metals in tomato, as it is an important component of people's diet in Jijel. The results indicated that $\mathrm{Pb}$ and $\mathrm{Cd}$ levels in tomato exceeded the permissible limits ( 0.1 and $0.05 \mathrm{mg} / \mathrm{kg}$, respectively) in the samples corresponding to all the studied sites. Similar to our results, Singh and Kumar (2006) had shown that although the heavy metal load was low in the soils, it was higher in the vegetable samples. $\mathrm{Zn}, \mathrm{Pb}$ and $\mathrm{Cd}$ in spinach and okra were in excess of the WHO limits. In the same context, Ray et al. (2010) recorded high levels of $\mathrm{Cd}$ and $\mathrm{Pb}$ $(1.1 \mathrm{mg} / \mathrm{kg})$ in cauliflower, cabbage and tomatoes, which were cultivated on anon-polluted soil. A research conducted in India showed that $\mathrm{Pb}$ and $\mathrm{Cd}$ levels in tomatoes exceeded the maximum permissible limit set by WHO/ FAO (Mohod, 2015). The results from the present work and earlier reports (Balkhair and Ashraf, 2016; Banerjee and Gupta, 2017; Liu et al., 2005; Muchuweti et al., 2006) demonstrate that plants are frequently contaminated with heavy metals, thus posing a threat to public health. 
Contrary to $\mathrm{Cd}$ and $\mathrm{Pb}, \mathrm{Zn}$ levels in tomatoes in the present study were below the WHO/FAO and Indian permissible limits (60 and $50 \mathrm{mg} / \mathrm{kg}$, respectively). The mean concentration recorded was $6.57 \pm 1.81 \mathrm{mg} / \mathrm{kg}$, ranging from 3.75 to $9.25 \mathrm{mg} / \mathrm{kg}$. Similar studies (Ali and Al-Quahtani, 2012; Bvenura and Afolayan, 2012; Oteef and Fawy, 2015; Tasrina et al., 2015) showed that Zn levels in tomatoes were below the WHO/FAO and Indian permissible limits; these levels however were higher than those obtained in this study.

Efficiency of different plants in adsorbing metals is evaluated by soil to plant transfer factors of metals (TF); this is an important mean for human health risk assessment (Khan et al., 2009). It is an index for the bioavailability of metals to plants, reflecting thus, the risk of human dietary exposure to these elements. High transfer factors reflect a relatively poor retention in soils or a strong uptake efficiency of vegetables. Low transfer factor reflects a strong adsorption of metals to the soil colloids (Tasrina et al., 2015). According to Kloke (1984), a TF lower than 0.1 indicates that the plant is excluding the element from its tissues - the greater is the TF, the greater are the chances of vegetables for metal contamination (Khan et al., 2009). In this study, the TF of different heavy metals from soil to vegetable are presented in Table 5.

In all the studied sites (except site 3), the TF values obtained in tomatoes for $\mathrm{Pb}$ and $\mathrm{Zn}$ were within the norm levels of 0.01 to 0.1 suggested by Kloke et al. (1984). However, the TF values obtained for Cd were higher than 0.1. Kloke et al. (1984) suggested that a TF higher than 0.5 is an indicator of anthropogenic contamination of the site. Then, it has been suggested to lower the limit to 0.2 instead of 0.5 , particularly in the case of leafy plants. In the present study, TF of $\mathrm{Cd}$ surpassed

Table 5. Transfer factors of heavy metal from Jijel soils into the vegetable samples.

\section{TF for heavy metals}

\begin{tabular}{lccc}
\hline Location & $\mathrm{Pb}$ & $\mathrm{Cd}$ & $\mathrm{Zn}$ \\
\hline 1 JIM & 0.01 & 0.7 & 0.02 \\
2 MZY & 0.03 & 0.01 & 0.04 \\
3 EMR & 0.004 & 0.12 & 0.08 \\
4 TAH & 0.02 & 1.18 & 0.03 \\
5 ELM & 0.012 & 0.29 & 0.03 \\
6 SDA & $*$ & 0.27 & 0.01 \\
7 KEN & 0.01 & 0.22 & 0.03 \\
8 END & $*$ & 0.13 & 0.02 \\
\hline
\end{tabular}

TF, transfer coefficient; JIM, Jimar; MZY, Mzayer; EMR, Emir Abdelkader; TAH, Tahir; ELM, Elmilia; SDA, Sidi Abdelaziz; KEN, Kennar; END, Endreau.

*Soil/vegetable ratio was not calculated, one of the results was below detection limit. the value of 0.2 in almost all of the studied sites, indicating an anthropogenic contamination. In site 4, TF was higher than 1 (1.18). It has been suggested that TF values less than 1 signify that the plants absorb but do not accumulate heavy metals. A TF of above 1 signifies instead that plants are hyperaccumulators and indicates that the uptake of heavy metals in vegetables are higher than in the soil (Balkhair and Ashraf, 2016; Chopra and Pathak, 2015; Hellen and Othman, 2016). In this regard, high TF in site 4 could be related to the high exchangeable $\mathrm{Cd}$ content in this site compared to other sites. These values are in agreement with those found by Mohammed and Jimoh (2014).

The overall TF observation of heavy metals showed that TF values of $\mathrm{Cd}$ were the highest when compared to $\mathrm{Pb}$ and $\mathrm{Zn}$ values from all locations, which may be due to its high mobility relative to other elements as well as its low soil retention capacity (Gharaibeh et al., 2016; Mirecki et al., 2015).

Those metals that have a high transfer factor migrate to the edible part of the plant much more easily than do those with a low transfer factor TF. A Transfer factor of 0.1 indicates that a plant is excluding the element from its tissues, while a TF of 0.2 for vegetables indicates that a risk of metal contamination by anthropogenic activities, which in turn calls for environmental monitoring of the area (Bassey et al., 2014). TF values differ among locations and the plant species, and the difference in TF between locations may be related to soil nutrient management, and physical and chemical properties of the soil (Balkhair and Ashraf, 2016; Tasrina et al., 2015).

To assess the human health risks of each pollutant, it is essential to estimate the exposure pathways of the target organisms. Therefore, to evaluate the potential human health risks in the area, EDI, HQ and HI were calculated.

Consumers of tomatoes grown in the Jijel area may be exposed to contamination by the presence of heavy metals. Table 6 presents HQ, HI and comparison of EDI with tolerable daily intake (TDI)

Table 6. Estimated daily intake, hazard quotients and hazard index for heavy metal exposure from tomato consumption.

\begin{tabular}{lcccc}
$\begin{array}{l}\text { Heavy } \\
\text { metals }\end{array}$ & EDI $\boldsymbol{~ g ~ k g ~}^{-1}$ day $^{-1}$ & $\mathrm{TDI}^{\mathrm{a}} \boldsymbol{\mu g ~ \mathbf { ~ g } ^ { - 1 } \text { day } ^ { - 1 }}$ & $\mathrm{HQ}$ & $\mathrm{HI}$ \\
\hline $\mathrm{Pb}$ & 2 & 3.6 & 0.51 & 0.434 \\
$\mathrm{Cd}$ & 0.7 & 1 & 0.76 & \\
$\mathrm{Zn}$ & 10.1 & 667 & 0.03 & \\
\hline
\end{tabular}

TDI, tolerable daily intake; $\mathrm{HI}$, hazard index; $\mathrm{HQs}$, hazard quotients; EDI, estimated daily intake.

${ }^{\mathrm{a} W H O}, 1993$. 
In this study, the means of $\mathrm{EDI}$ of $\mathrm{Pb}, \mathrm{Cd}$ and $\mathrm{Zn}$ was below the TDI set by WHO/FAO. The HI values for adults decreased in the order of $\mathrm{Zn}>\mathrm{Pb}>\mathrm{Cd}$. These results indicated that $\mathrm{Cd}$ was the main element contributing to the potential of health risk, followed by $\mathrm{Pb}$. This is in agreement with the results reported for the greenhouse vegetable production (GVP) area in Nanjing City, Southeast China (Hu et al., 2014). The mean HI of the three elements range from 0.24 to 0.54 , and the maximum values are also below the safety threshold. In general, the HIs in all the studied areas are lower than 1, signifying that it is not risky for the consumers to consume the vegetables (tomatoes) cultivated in these areas. These results agree with results obtained in a study conducted in Algeria by Cherfi et al. (2014) on different crops, indicating that $\mathrm{HI}$ and $\mathrm{HQ}(\mathrm{Pb}$ and $\mathrm{Zn})$ are less than 1 in tomatoes, with the exception of potatoes, which had an HQ greater than 1, suggesting a potential health risk for consumers. Furthermore, the results obtained in this study are in agreement with an earlier research conducted by Han et al. (2018), Hua et al. (2017) and Hub et al. (2017). However, the HQ for $\mathrm{Cd}$ in sites 5, 6 and 7 are greater than 1 , suggesting that the inhabitants are experiencing a significant potential health risk, especially from the consumption of tomatoes cultivated in these sites. Also, the fact that the $\mathrm{HQ}$ values of $\mathrm{Pb}$ and $\mathrm{Cd}$ are close to the threshold presents a source of uncertainty for the consumers of these products. However, the HQs of $\mathrm{Zn}$ are generally less than 1 , signifying that it is not risky for people to consume these elements. The potential health risk of $\mathrm{Zn}$ is the lowest, which may be ascribed to its higher RfD. However, contrary to our study, the HI values for $\mathrm{Pb}$ and $\mathrm{Cd}$ were found to be higher than the safe threshold of 1 in previous studies (Balkhair and Ashraf, 2016; Zeng et al., 2018; Zheng et al., 2013).

\section{Conclusion}

These results show that the yield of extraction by HF was higher than the yield of Aqua regia, probably in relation to the nature of the soil and the presence of silicate. Such variables must be taken into consideration to avoid misinterpreted results in biomonitoring studies and hazard assessment. Heavy metal contents varied from one site to another. According to the IPI values, all the sites are contaminated by heavy metals with different degrees of pollution. However, we noticed that $\mathrm{Pb}, \mathrm{Cd}$ and $\mathrm{Zn}$ presented high concentrations in the cultivated soils, compared to the corresponding control soils, reflecting an influence of agricultural activities. This must be taken into consideration to avoid any potential anthropogenic pollution in the future. In fact, $\mathrm{Pb}$ and $\mathrm{Cd}$ in tomatoes exceeded the permissible limit set by WHO/FAO and EU in all the samples; in few sites, TF was higher than 0.5 , which could already indicate anthropogenic pollution. In general, the HIs in all the studied areas are less than 1, suggesting that it is not risky for people to consume the vegetables (tomatoes) cultivated in these areas. However, the HQ for $\mathrm{Cd}$ in sites 5, 6 and 7 are greater than 1, suggesting that inhabitants are experiencing a significant potential health risk solely from the consumption of tomatoes cultivated in these sites. Also, some attention should be paid to the lead and $\mathrm{Cd}$ content in the tomatoes whose $\mathrm{HQ}$ values approach the threshold value of 1 . However, the HQs of $\mathrm{Zn}$ are generally less than 1 , suggesting that it is not risky for the people to consume these elements.

To draw a representative image about soil and crop pollution in Algeria, further research is required to evaluate the concentration of additional heavy metals in different agricultural soils and vegetable crops in different states of the country. To the best of our knowledge, this is the first study conducted on the agricultural soils of Jijel, and this could serve as reference for future studies to monitor pollution in Jijel and the surrounding areas.

\section{Conflict of interest}

The authors declare no conflicts of interest with respect to research, authorship and/or publication of this article.

\section{Compliance with ethical standards}

This work has been conducted according to the ethical standards of scientific comity of University of Jijel.

\section{Funding}

This research received no specific grant from any funding agency in the public, commercial or not-for-profit sectors.

\section{References}

Abosede, O.A., 2017. Review on heavy metals contamination in the environment. European Journal of Earth and Environment 4(1): 1-6.

Abrid, D., EL Hmaidi, A., Abdallaoui, A. and Essahlaoui, A., 2013. Spatial variation in concentrations of the metallic traces elements in sediments of Sidi Chahed dam (Meknes, Morocco). European Journal of Scientific Research 106: 503-511.

AFNOR(NF X31-147), 1996. Qualité des sols-Sols-sédiments-Mise en solution totale par attaque acide.

Ahaneku, I.E. and Sadiq, B.O., 2014. Assessment of heavy metals in Nigerian agricultural soils. Polish Journal of Environmental Studies 23(4): 1091-1100.

Alam, M.G.M., Snow, E.T. and Tanaka, A., 2003. Arsenic and heavy metal concentration of vegetables grown in Samta village, Bangladesh. The Science of the Total Environment 308: 83-96. https://doi.org/10.1016/S0048-9697(02)00651-4.

Alghobar, M.A. and Suresha, S., 2017. Evaluation of metal accumulation in soil and tomatoes irrigated with sewage water from Mysore city, Karnataka, India. Journal of the Saudi Society of 
Agricultural Sciences 16: 49-59. https://doi.org/10.1016/j. jssas.2015.02.002

Ali, M.H.H. and Al-Qahtani, K.M., 2012. Assessment of some heavy metals in vegetables, cereals and fruits in Saudi Arabian markets. Egyptian Journal of Aquatic Research 38(1): 31-37. https://doi. org/10.1016/j.ejar.2012.08.002

Atek, M., Laid, Y., Mezimeche, N., Boutekdjiret, L. and Lebcir, H., 2010. L’Obésité chez l'adulte de 35 à 70 ans en Algérie, pp 1-93. Projet TAHINA. Institut national de santé publique Alger, Algérie.

Badra, A. and Qu, A., 2005. Guide de référence en fertilisation. 1 ère édition. Centre de de référence en agriculture et agroalimentaire du Québec, Québec, pp. 1-15.

Baize, D., 1997. Teneurs totales en éléments traces métalliques dans les sols (France): références et stratégies d'interprétation. INRA, Paris, 410p.

Balkhair, K.S. and Ashraf, M.A., 2016. Field accumulation risks of heavy metals in soil and vegetable crop irrigated with sewage water in western region of Saudi Arabia. Saudi Journal of Biological Sciences 23(1): S32-S34. https://doi.org/10.1016/j. sjbs.2015.09.023

Banerjee, U.S. and Gupta, S., 2017. Metal contamination in cultivated vegetables and agricultural soils irrigated with untreated industrial wastewater. Environmental Pollution and Protection 2(1): 15-22. https://doi.org/10.22606/epp.2017.21003

Bassey, F.I., Iwegbue, C.M.A., Obi-Iyeke, G.E., Tesi, G.O., Rotu, A.R., Gobe, O.A. and Tsafe, A.I., 2014. Heavy metals in soils and tomatoes grown in urban fringe environment in Asaba, Delta State, Nigeria. Nigerian Journal of Basic and Applied Science 22(1-2): 27-31. https://doi.org/10.4314/njbas.v22i1.5

Benson, N.U., Anake, W.U. and Etesin, U.M., 2014. Trace metals levels in inorganic fertilizers commercially available in Nigeria. Journal of Scientific Research \& Reports 3(4): 610-620. https:// doi.org/10.9734/JSRR/2014/7465

Bhuiyan, M.A.H., Suruvi, N.I., Dampare, S.B., Islam, M.A., Quraishi, S.B., Ganyaglo, S. and Suzuki, S., 2011. Investigation of the possible sources of heavy metal contamination in lagoon and canal water in the tannery industrial area in Dhaka, Bangladesh. Environmental Monitoring and Assessment 175: 633-649. https://doi.org/10.1007/s10661-010-1557-6

Brallier, S., Harrison, R.B., Henry, C.L. and Dongsen, X., 1996. Liming effects on availability of $\mathrm{Cd}, \mathrm{Cu}, \mathrm{Ni}$ and $\mathrm{Zn}$ in a soil amended with sewage sludge 16 years previously. Water, Air and Soil Pollution 86: 195-206. https://doi.org/10.1007/BF00279156

Brigden, K., Stringer, R. and Santillo, D., 2002. Heavy metal and radionuclide contamination of fertilizer products and phosphogypsum waste produced by the Lebanese Chemical Company, Lebanon. Greenpeace Research Laboratories Technical Note 13.

Bvenura, C. and Afolayan, A.J., 2012. Heavy metal contamination of vegetables cultivated in home gardens in the Eastern Cape. South African Journal of Science 108(9-10): 1-6. https://doi. org/10.4102/sajs.v108i9/10.696

Cai, Q., Long, ML., Zhu, M., Zhou, QZ., Zhang, L. and Liu, J., 2009. Food chain transfer of cadmium and lead to cattle in a leadzinc smelter in Guizhou, China. Environmental Pollution 157: 3078-3082. https://doi.org/10.1016/j.envpol.2009.05.048
Calvet, R., 2003. Le sol propriétés et fonctions, tome 1 constituants et structure, phénomènes aux interfaces. France Agricole, Paris, pp. 84-197.

CCME (Canadian Council of Ministers of the Environment). 1999. Canadian environmental quality guidelines. Canadian Council of Ministers of the Environment, Winnipeg, Manitoba.

CCME (Canadian Council of ministers of the Environment). 2007. Canadian soil quality guidelines for the protection of environmental and human health. National Guidelines and Standards Office. Publication No. 1299. Ottawa, Ontario, pp. 1-7.

Chen, H., Teng, Y., Lu, S., Wang, Y. and Wang, J., 2015. Contamination features and health risk of soil heavy metals in China. Science of the Total Environment 512-513: 143-153. https://doi. org/10.1016/j.scitotenv.2015.01.025

Cherfi, A., Abdoun, S. and Gaci, O., 2014 Food survey: levels and potential health risks of chromium, lead, zinc and copper content in fruits and vegetables consumed in Algeria. Food and Chemical Toxicology 70: 48-53. https://doi.org/10.1016/j.fct.2014.04.044

Chon, A.H.T., Ahn, J.S. and Jung, M.C., 1998. Seasonal variations and chemical forms of heavy metals in soils and dusts from the satellite cities of Seoul, Korea. Environmental Geochemistry and Health 20: 77-86. https://doi.org/10.1023/A:10065937084.64

Chopra, A.K. and Pathak, C., 2015. Accumulation of heavy metals in the vegetables grown in wastewater irrigated areas of Dehradun, India with reference to human health risk. Environmental Monitoring and Assessment 187(7): 445. https://doi.org/10.1007/ s10661-015-4.648-6

CNEMC (China National Environmental Monitoring Center). 1990. The background concentrations of soil elements of China. China Environmental Science Press, Beijing, China.

CNEPA (China National Environmental Protection Agency). 2006. Environmental quality evaluation standard for farmland of greenhouse vegetables production. Beijing, China.

Corguinha, A.P.B., de Souza, G.A., Gonçalves, V.C., de Andrade Carvalho, C., de Lima, W.E.A., Martins, F.A.D. and Guilherme, L.R.G., 2015. Assessing arsenic, cadmium, and lead contents in major crops in Brazil for food safety purposes. Journal of Food Composition and Analysis 37: 143-150. https://doi.org/10.1016/j. jfca.2014.08.004

Durand, J.H., 1983. Les sols irrigable: étude pédologique. impr. Imbert, Sorbonne, 190p.

Gharaibeh, M.A., Albalasmeh, A.A., Marschner, B. and Saleem, Y., 2016. Cadmium uptake and translocation of tomato in response to simulated irrigation water containing elevated concentrations of cadmium and zinc in clayey soil. Water, Air, Soil Pollution 227(5): 133. https://doi.org/10.1007/s11270-016-2829-8

Guero, Y., Tidjani, A.D., Ambouta, K.J.M., Feidt, C., Sterckeman, T. and Echevarria, G., 2013. Evaluation de la contamination des sols par les éléments traces métalliques dans les zones urbaines et périurbaines de la ville de Niamey (Niger). Revue des Bioressources 3: 82-95. https://doi.org/10.12816/0008874

Han, W., Gao, G., Geng, J., Li, Y. and Wang, Y., 2018. Ecological and health risks assessment and spatial distribution of residual heavy metals in the soil of an e-waste circular economy park in Tianjin, China. Chemosohere 197: 325-335. https://doi.org/10.1016/j. chemosphere.2018.01.043 
Harmanescu, M., Alda, L.M., Bordean, D.M., Gogoasa, I. and Gergen, I., 2011. Heavy metals health risk assessment for population via consumption of vegetables grown in old mining area: a case study: Banat County, Romania. Chemistry Central Journal 6: 64. https://doi.org/10.1186/1752-153X-5-64

Hellen, L.E. and Othman, O.C., 2016. Heavy metal levels in soil, tomatoes and selected vegetables from Morogoro Region, Tanzania. International Journal of Environmental Monitoring and Analysis 4(3): 82. https://doi.org/10.11648/j.ijema.20160403.13

Herath, D., Pitawala, A. and Gunatilake, J., 2016. Heavy metals in road deposited sediments and road dusts of Colombo Capital, Sri Lanka. Journal of the National Science Foundation of Sri Lanka 44: 193-202. https://doi.org/10.4038/jnsfsr.v44i2.8000

Hoenig, M., and Thomas, P. (2002). Préparation déchantillons de l'environnement pour analyse minérale. Ed. Techniques Ingénieur, St. Denis, France.

Hu, W., Chen, Y., Huang, B. and Niedermann, S., 2014. Health risk assessment of heavy metals in soils and vegetables from a typical greenhouse vegetable production system in China. Human and Ecological Risk Assessment 20 (5): 1264-1280. https://doi.org/10 $.1080 / 10807039.2013 .831267$

Hua, B., Jia, X., Hu, J., Xu, D., Xia, F. and Li, Y., 2017. Assessment of heavy metal pollution and health risks in the soil-plant-human system in the Yangtze River Delta, China. International Journal of Environmental Research and Public Health 14: 1042. https://doi. org/10.3390/ijerph14091042

Hub, W., Huang, B., Tian, K., Holm, P.E. and Zhang, Y., 2017. Heavy metals in intensive greenhouse vegetable production systems along Yellow Sea of China: levels, transfer and health risk. Chemosphere 167: 82-90. https://doi.org/10.1016/j.chemosphere.2016.09.122

Jung, M.C. and Thornton, I., 1996. Heavy metal contamination of soils and plants in the vicinity of a lead- zinc mine (Korea). Applied Geochemistry 11: 53-59. https://doi. org/10.1016/0883-2927(95)00075-5

Kassaoui, H., Lebkiri, M., Lebkiri, A., Rifi, E.H., Badoc, A. and Douira, A., 2009. Bioaccumulation de métaux lourds chez la tomate et la laitue fetilisées par les boues d'une station d'épuration. Bulletin De La Société De Pharmacie De Bordeaux 148: 77-92.

Kebir, T. and Bouhadjera, K., 2011. Effects of heavy metals pollution in soil and plant in the industrial area, West ALGERIA. Journal of the Korean Chemical Society 55: 6. https://doi.org/10.5012/ jkcs.2011.55.6.1018

Kehila, Y., Matejka, G., Gourc, J.P., Alouemine, S., Adjiedj, A., Foully, B., Naquin, P. and Ngninkam, E., 2006. Approche méthodologique pour la mise en place d'outils de conception, de suivi et de contrôle des installations de traitement et d'élimination des déchets solides urbains dans les Pays en Développement (PED): rôle de la recherche interuniversitaire. Mostaganem, Algérie.

Kelepertzis, E., 2014. Accumulation of heavy metals in agricultural soils of Mediterranean: insights from Argolida basin, Peloponnese, Greece. Geoderma 221-222: 82-90. https://doi.org/10.1016/j. geoderma.2014.01.007

Khan, S., Farooq, R., Shahbaz, S., Khan, M.A. and Sadique, M., 2009. Health risk assessment of heavy metals for population via consumption of vegetables. World Applied Sciences Journal 6(12): 1602-1606.
Kloke, A., Sauerbeck, D.R. and Vetter, H., 1984. The contamination of plants and soils with heavy metals and transport of metals in terrestrial food chain. In: Nriagu J.O. (ed.) Changing metal cycles and human health. Report of the Darlem workshop on changing metals cycles and human health. Springer, Berlin, Germany, pp. 113-141.

Kouchou, A., Rais, N., Elsass, F., Duplay, J., Fahli, N. and El Ghachtouli, N., 2017. Effects of long-term heavy metals contamination on soil microbial characteristics in calcareous agricultural lands (Saiss plain, North Morocco). Journal of Materials and Environmental Science 8(2): 691-695.

Li, J., Lu, Y., Yin, W., Gan, H., Zhang, C., Deng, X. and Lian, J., 2009. Distribution of heavy metals in agricultural soils near a petrochemical complex in Guangzhou, China. Environmental Monitoring and Assessment 153(1-4): 365-375. https://doi. org/10.1007/s10661-008-0363-x

Liu, M., Li, Y., Zhang, W. and Wang, Y. (2013). Assessment and spatial distribution of zinc pollution in agricultural soils of Chaoyang, China. Procedia Environmental Sciences 18: 283-289. https://doi. org/10.1016/j.proenv.2013.04.037

Liu, W.H., Zhao, G.Z., Ouyang, Z.Y., Derlund, L.S. and Liu, G.H., 2005. Impacts of sewage irrigation on heavy metal distribution and contamination in Beijing (China). Environment International 31: 805-812. https://doi.org/10.1016/j.envint.2005.05.042

Lygren, E., Gjessing, E. and Berglind, L. 1984. Pollution transport from a highway. Science of the Total Environment 1-4: 147-159. https://doi.org/10.1016/0048-9697(84)90389-9

Lu, J.S., Zhang, Z.L., Liu, Y., Dai, J. and Wang, X., 2012. Sources identification and hazardous risk delineation of heavy metals contamination in Rizhao City. Acta Geographica Sinica 67(7): 971-984.

Maas, S., Scheifler, R., Benslama, M., Crini, N., Lucot, E., Brahmia, Z., and Giraudoux, P. 2010. Spatial distribution of heavy metal concentrations in urban, suburban and agricultural soils in a Mediterranean city of Algeria. Environmental Pollution 158(6): 2294-2301. https://doi.org/10.1016/j.envpol.2010.02.001

Matech, F., Zaakour, F., Moustarhfer, K., Chemsi, Z., Benazzouz, I. and Saber, N. 2014. Les sols agricoles irrigués par les eaux d'oued Hassar (Médiouna-Maroc): approche agronomique et environnementale. Journal of Materials and Environmental Science 5(S2): 2540-2543.

Mathieu, C. and Pieltain, F. 2003. Analyse chimique des sols méthodes choisies. Editions Tec et Doc, Lavoisier, Cachan, France, 408p.

Micó, C., Peris, M., Sánchez, J. and Recatalá, L. 2006.Heavy metal content of agricultural soils in a Mediterranean semiarid area: the Segura River Valley (Alicante, Spain). Chemosphere 65: 863-872. https://doi.org/10.1016/j.chemosphere.2006.03.016

Mirecki, N., Agič, R., Šunić, L., Milenković, L., and Ilić, Z.S. 2015. Transfer factor as indicator of heavy metals content in plants. Fresenius Environmental Bulletin 24(11C): 4212-4219.

Mohammed, M.I. and Jimoh, W.L.O. 2014. Relationship between transfer factor and enrichment factor from the soil and vegetable grown in irrigated farmlands of Kaduna Metropolis Nigeria. International Journal of Engineering Science Invention 3(3): $17-24$. 
Mohod, C. 2015. A review on the concentration of the heavy metals in vegetable samples like spinach and tomato grown near the Area of Amba Nalla of Amravati City. International Journal of Innovative Research in Science, Engineering and Technology 4(5): 2788-2792. https://doi.org/10.15680/IJIRSET. 2015.0405019

Mpundu, M.M., Useni, S.Y., Mwamba, M., Kateta, M.G., Mwansa, M., Ilunga, K. and Nyembo, K.L. 2013. Teneurs en éléments traces métalliques dans les sols de jardins potagers en Lubumbashi et risques de contamination des cultures. Journal of Applied Biosciences 65: 4957-4968.

Muchuweti, M., Birkett, J.W., Chinyanga, E., Zvauya, R., Scrimshaw, M.D. and Lester, J.N. 2006. Heavy metal content of vegetables irrigated with mixtures of wastewater and sewage sludge in Zimbabwe: implications for human health. Agriculture, Ecosystems and Environment 112(1): 41-48. https://doi. org/10.1016/j.agee.2005.04.028

Naili, S., Merzoug, A.N., Lakehal, A. and Ahras, D.S. 2016. Détermination des teneurs en éléments traces métalliques des sols cultives dans la région de Constantine par spectrométrie XRF. Third International Conference on Energy, Materials, Applied Energetics and Pollution. Applied Energetics and Pollution Laboratory (LAEP), Mentouri Brothers 'Constantine 1 University, Constantine, Algeria, pp. 103-109.

Oteef, M.D.Y., Fawy, K.F., Abd-Rabboh, H.S.M. and Idris, A.M. 2015. Levels of zinc, copper, cadmium, and lead in fruits and vegetables grown and consumed in Aseer Region, Saudi Arabia. Environmental Monitoring and Assessment 187(11): 676. https:// doi.org/10.1007/s10661-015-4.905-8

Ray, L., Banerjee, D., Bairagi, H., Mukhopadhyay, S., Pal, A. and Bera, D. 2010. Heavy metal contamination in fruits and vegetables in two districts of West Bengal, India. Electronic Journal of Environmental, Agricultural and Food Chemistry 9: 1423-1432.

Santoro, A., Held, A., Linsinger, T.P.J., Perez, A. and Ricci, M. 2017. Comparison of total and aqua regia extractability of heavy metals in sewage sludge: the case study of a certified reference material. TrAC - Trends in Analytical Chemistry 89: 34-40. https://doi. org/10.1016/j.trac.2017.01.010

Scancar, J., Hovat, M. and Milacic, R. 2000. Comparison of various digestion and extraction procedures in analysis of heavy metals in sediments. Water, Air, Soil Pollution 118: 87-99. https://doi. org/10.1023/A:1005187602820

Shahbazi, A., Soffianian, A.R. and Mirghaffari, N. 2017. Impact assessment of agricultural activities on heavy metal accumulation in soil. AES Bioflux 9(2): 99-108.

Shahid, M., Dumat, C., Khalid, S., Schreck, E., Xiong, T. and Niazi, N.K. 2016. Foliar heavy metal uptake, toxicity and detoxification in plants: a comparison of foliar and root metal uptake. Journal of Hazardous Materials 325: 36-58. https://doi.org/10.1016/j. jhazmat.2016.11.063

Singh, S. and Kumar, M. 2006. Heavy metals load of soil, water and vegetables. Environmental Monitoring and Assessment 120: 79-91. https://doi.org/10.1007/s10661-005-9050-3

Soubrand-Colin, M. 2004. Localisation, distribution et mobilité des ETM dans des sols développés sur roches basaltiques en climat tempéré. Université de Limoges. Limoges, France, 168p.

Tasrina, R.C., Rowshon, A., Mustafizur, A.M.R., Rafiqul, I. and Ali, M.P. 2015. Heavy metals contamination in vegetables and its growing soil. Journal of Environmental Analytical Chemistry 2(3): 142. https://doi.org/10.4172/2380-2391.1000142

USEPA (United States, Environmental Protection Agency). (2017). Integrated risk in-formation system. Environmental Protection Agency, Washington, DC.

Wei, B. and Yang, L. 2010. A review of heavy metal contaminations in urban soils, urban road dusts and agricultural soils of China. Microchemical Journal 94: 99-107. https://doi.org/10.1016/j. microc.2009.09.014

World Health Organization (WHO). (1993). Evaluation of certain food additives and contaminants. Forty-first report of the joint FAO/WHO expert committee on food addi- tives, WHO Tech. Report Series No. 837.

Yan, X., Zhang, F., Gao, D., Zeng, C., Xiang, W. and Zhang, M. 2013. Accumulations of heavy metals in roadside soils close to Zhaling, Eling and Nam Co Lakes in the Tibetan Plateau. International Journal of Environmental Research and Public Health 10(6): 2384-2400. https://doi.org/10.3390/ijerph10062384

Yu, L., Cheng, J. and Zhan, J. 2016. Environmental quality and sources of heavy metals in the topsoil based on multivariate statistical analyses. Natural Hazards 81(3): 1435-1445. https://doi. org/10.1007/s11069-015-2130-y

Zeng, L., Zhou, F., Zhang, X., Qin, J. and Li, H. 2018. Distribution of heavy metals in soils and vegetables and health risk assessment in the vicinity of three contaminated sites in Guangdong. Human and Ecological Risk Assessment: An International Journal 24(7): 1901-1915. https://doi.org/10.1080/10807039.2018.1431043

Zheng, J., Chen, K-H., Yan, X., Chen, S-J., Hu, G-C., Peng, X-W., Yuan, J-g., Mai, B-X. and Yang, Z-Y. 2013. Heavy metals in food, house dust, and water from an e-waste recycling area in South China and the potential risk to human health. Ecotoxicology and Environmental Safety 96: 205-212. https://doi.org/10.1016/j. ecoenv.2013.06.017

Zheng, Y.J., Chen, Y.P., Maltby, L. and Jin, X.L. 2016. Highway increases concentrations of toxic metals in giant panda habitat. Environmental Science and Pollution Research 23, 21262-21272. https://doi.org/10.1007/s11356-016-7221-0 